\title{
Attitude Toward Democracy In Pakistan: Secondary School Teachers' Perceptions
}

Muhammad Sarwar, University of Sargodha, Pakistan

Muhammad Imran Yousuf, PMAS-Arid Agriculture University, Pakistan

Shafqat Hussain, GC University, Faisalabad, Pakistan

\begin{abstract}
The study aimed at exploring the public sector secondary school teachers' perceptions for development of democratic values and strategies to improve the democratic system and attitudes toward democracy. Sixty secondary school teachers were selected as a sample. The qualitative data in the form of interview responses were collected to explore teachers' perceptions about democracy, problems in the smooth running of democracy and remedies to these problems. Fivepoint Likert-type attitude toward democracy scale (ATDS) was developped to assess the attitude of secondary school teachers toward democracy. The data were analysed by applying one sample ttest. The study provide discussion at concusions drawn about democratic values and attitude of teachers toward democracy.
\end{abstract}

Keywords: Democracy, Democratic Attitude, Teachers' Perception, Democratic Values, Government System.

\section{INTRODUCTION}

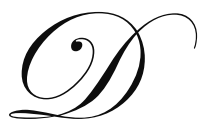

emocracy has four basic pillars: 1. replacing the government through free and fair elections, 2. participation of the people as citizens in politics and civic life, 3. respect for human rights, and 4. observation of the rule of law. The basic idea behind human rights is that there are a set of fundamental rights that everyone everywhere in the world is entitled to (Akbari, 2008). Positive attitude toward democracy and training of the citizens are major components of a democratic society. Citizenship education prepares children for liberal democracy and is concerned with particular forms of action, behaviour and ways of thinking (Pike, 2008). Citizenship education became a compulsory part of the National Curriculum in England and Wales in 2002. Citizenship education is treated as a contemporary example of the educationalization of social problems (Hodgson, 2008). The acceptance of democratic values is a necessary precondition for democracy (Daniel et al, 2006). Political parties are universally regarded as essential components of democratic regimes but often perceived in very negative terms: they are said to be self-interested, untrustworthy, corrupt, incapable of providing accountable and effective governance challenged by interest groups, social movements, and the media (WEBB, 2005).

Democracy is not only a process but rather an attitude and something out of self-perception. It respects other's opinions and aims for social justice, equal opportunity, and peoples rights of liberty. Political ideas, values, and beliefs of the citizens are important components in democracy especially in societies undergoing democratic transition (Hu, 2003). Every society consists of two groups the elite and the citizens - and democracy is conceptualized as rule by the citizens (Acemoglu and Robinson, 2006). Elites are persons who have high social positions power, influence and capability to control over resources at least within their environments (Hu, 2003). In the dichotomous distinction between democracies and non-democracies, the latter are understood as situations of relative political inequality where the elite hold all de jure political power. In contrast to that, democracy means government by the people and for the people, resulting in political equality. Although political institutions determine de jure power, it does not hold for de facto power (Acemoglu and Robinson, 2006).

The existence of pro-democracy attitudes among a majority of the population is a necessary condition for democracy Democratic survivability revolves around changes in political attitudes, toward a greater valorization of 
democracy (Tessler and Altinoglu, 2004). Democratic regime is consolidated if a strong majority of public opinion, even in the midst of major economic problems and deep dissatisfaction with incumbents, holds the belief that deemocratic procedure and institutions are the most appropriate way to govern the collective life. Trust in government is a mainstay of democracy (Christensentom, 2003). Trust may be subjected to ambiguous interpretation, and the causal link between trust and good government is a contested one (Braithwaite and Levi 1998, Rothstein and Stolle 2002). Democracy depends on the active engagement of citizens, not just in voting, but in developing and participating in sustainable and cohesive communities. The schools are also required to show, through inspection, how they are preparing learners for citizenship (Oslera and Starkey, 2005). In Pakistan there is no compulsory subject like citizenship. This may be one of the hindrances in the development of democratic attitude in the Pakistani society. Values are defined as desirable trans-situational goals, varying in importance, that serve as guiding principles in people's lives (Shechtman, 2002). More democratic-minded people tend to be younger, bettereducated city dwellers, with higher incomes, and white-collar jobs (Nathan, 2004).

As the perceptions of citizens play a key role in the development and working of a democratic system. Citizens are taught in the schools hence the perceptions of school teachers particularly secondary school teachers about democracy and their attitudes are very significant because secondary education is compulsory for citizenship. As a result, there is an urgent need for research to know the perceptions and attitudes of Secondary school teachers toward democratic institutions and processes in Pakistan where democracy has recently been restored after several years of army managed government. This study intends to explore the perceptions and attitude of seconday school teachers.

\section{Objectives of the Study}

- To explore the public sector secondary school teachers' perceptions about development of democratic values in schools.

- To explore the teachers' percepions about deficiencies in the democratic system of Pakistan.

- $\quad$ To explore the teachers' percepions about the strategies to improve the democratic system.

\section{Procedure and Instrument}

The study was delimited to three districts of Punjab Province, Pakistan i.e. district Sargodha, district Faisalababd, and district Rwalpindi. Twenty secondary school teachers from each district were selected randomly and so sample of 60 teachers was selected. The teachers were contacted in their free period and were requested to participate in the study. Attitude toward democracy scale (ATDS) was developed and administered to sample teachers. Factor analysis was done to check the construct validity of the scale. Twenty-six items to which principal component analysis was applied were collected under five factors, whose engine values are greater than 1.00. The results are presented in thwe form of qualtative and quantitative anaysis.

\section{Results of Quantitave Analysis}

Table 1: Mean, Standard Deviation and One sample t-test of attitude toward Democracy Score

\begin{tabular}{|c|c|c|c|c|c|c|c|}
\hline Variable & $\mathbf{N}$ & Mean & Std. Deviation & Scale Mean & t & df & Sig. (2-tailed) \\
\hline $\begin{array}{c}\text { Attitude toward } \\
\text { Democracy }\end{array}$ & 60 & 49.57 & 10.84 & 54 & -3.17 & 59 & .002 \\
\hline
\end{tabular}

To determine the teachers Attitude Toward Democracy (ATD), the expected total mean was $\mathrm{M=54.00}$ and the mean obtained from ATD was $M=49.57$. The results for ATD indicate that there is a significant difference between expected mean and the mean obtained from the ATDS $\left(\mathrm{t}_{(60)}=-3.17, \mathrm{p}<.002\right)$. According to this finding, the mean obtained from the ATDS is significantly lower than the expected total mean. So, it can be said that the secondary school teachers disagree mainly with the items related to attitude toward democracy and have negative attitude toward democracy. 
Table 2: One sample t-test of Acceptance of Democracy Score

\begin{tabular}{|c|c|c|c|c|c|c|c|}
\hline Variable & $\mathbf{N}$ & Mean & Std. Deviation & Scale Mean & t & df & Sig. (2-tailed) \\
\hline $\begin{array}{c}\text { Acceptance of } \\
\text { Democracy }\end{array}$ & 60 & 25.20 & 6.06965 & 27 & -2.297 & 59 & .025 \\
\hline
\end{tabular}

The data for teachers Acceptance Of Democracy (AOD) shows that expected total mean was $\mathrm{M}=27.00$ and the mean obtained mean was $M=25.20$. The results indicate that there is a significant difference between expected mean and the mean obtained from the AODS $\left(\mathrm{t}_{(60)}=-2.297, \mathrm{p}<.02\right)$. According to this finding, the mean obtained from the acceptance of democracy is significantly lower than the expected total mean $(M=27.00)$. So, it can be said that the public sector secondary school teacher do not accept democracy.

Table 3: Mean, Standard Deviation and One sample t-test of attitude toward Government

\begin{tabular}{|c|c|c|c|c|c|c|c|}
\hline Variable & $\mathbf{N}$ & Mean & Std. Deviation & Scale Mean & t & df & Sig. (2-tailed) \\
\hline $\begin{array}{c}\text { Attitude toward } \\
\text { Government }\end{array}$ & 60 & 8.30 & 2.77 & 9 & -1.956 & 59 & .05 \\
\hline
\end{tabular}

To determine the Attitude Toward Government (ATG), one-sample t-test was applied and tested the difference between the expected total mean $(M=9.00)$ and the mean obtained mean $(M=8.30)$. The results in Table 3 indicate that there is a significant difference between expected mean and the mean obtained from the ATGS ( $\mathrm{t}_{(60)}=-$ $1.96, \mathrm{p}<.05)$. According to this finding, the mean obtained from the acceptance of democracy is significantly lower than the expected total mean $(M=9.00)$. So, it can be said that the public sector secondary school teachers have negative attitude toward the government.

Table 4: Mean, Standard Deviation and One sample t-test of attitude toward Institutions Score

\begin{tabular}{|c|c|c|c|c|c|c|c|}
\hline Variable & $\mathbf{N}$ & Mean & Std. Deviation & Scale Mean & t & df & Sig. (2-tailed) \\
\hline $\begin{array}{c}\text { Attitude toward } \\
\text { Institutions }\end{array}$ & 60 & 16.0667 & 3.54088 & 18 & -4.229 & 59 & .000 \\
\hline
\end{tabular}

To determine the Attitude Toward Institutions (ATI), one-sample t-test was applied and tested the difference between the expected total mean $(M=18.00)$ and the mean obtained mean $(M=16.07)$. The results (given in table 4) indicate that there is a significant difference between expected mean and the mean obtained from the ATIS $\left(\mathrm{t}_{(60)}=-4.23, \mathrm{p}<.00\right)$. According to this finding, the mean obtained from the Attitude toward institutions is significantly lower than the expected total mean $(M=9.00)$. So, it can be said that the public sector secondary school teachers have negative attitude toward the government institutions.

\section{Results of Qualitatve Analysis}

The qualitative data in the form of interview responses were collected to explore the secondary school teachers' perceptions about democracy, problems in the smooth running of a democracy and remedies to these problems. The secondary school teachers viewed that democratic values were not being promoted in the secondary schools, and school teachers were not more democratic than other people of the society. Younger teachers tend to be more democratic than older ones. Class-teacher's democratic behaviour was considered very helpful for the development of democratic values so, the teachers were held responsible for the development of democratic values with the cooperation of the parents and society. Open climate and proper method of teaching were considered most appropriate for the development of democratic values in the secondary school students.

The public sector secondary school teachers declared that non-availability of justice, autocratic style of elected government, no respect for law, terrorism, unemployment, immature non-serious and corrupt government body, interference of army in democracy were major threats for the democracy. The public sector secondary school teachers perceived that political stability, provision of justice, good governance, merit based selection, posting and promotion of government officials, and the same criterion to select the honest and hardworking people for the key 
posts, democratic education, rule of law, and accountability of every bureaucracy and political person can help the country to become a true democratic state.

\section{CONCLUSIONS AND DISCUSSION}

Studies of teacher effectiveness indicate that teachers' perceptions, attitudes and beliefs directly influence their decision-making and actual behavior in the classroom (Pajares, 1992). Whereas this study indicates that public sector secondary school teachers in Pakistan perceive that the schools were not developing democratic values in the students. This may be due to the reason that neither the society nor the teacher training programmes have special emphasis on the development of democratic values in the prospective teachers. Moreover, the rules and regulations for postings and transfers in particular and on other matter in general are not being implemented in the education department.

The public sector secondary school teachers perceived that non availability of justice, autocratic style of elected government, no respect for law, terrorism, unemployment, non-serious and corrupt government body, and interference of army in democracy were major threats for the democracy. The role of the ruling party and opposition is very important in the development, continuity and sustainability of a political system because power groups always try to create differences between them. These forces particularly target the opposition therefore opposition must play positive role in this respect. Independent and just judicial system can ensure the right man for the right job and accountability. Pakistan has been ruled by the Army for the most of its ruled period. The weaknesses pointed out by the secondary school teachers are the true reflection of main societal problems which demands immediate solutions. There has been interplay of military and so called democratic governments in which rich, powerful people can only be elected as members of local and legislative bodies and as common people could not have due representation in the democratic system that is why problems of common people are not understood and addressed. The democracy in Pakistan could not perform well due to lack of democracy within the party structure and preoccupation with the sole objective of grabbing power.

The suggestions put forward by the teachers reflect their development and societal needs in Pakistan. They think that stable political system will provide base for the provision of just judicial system in the country in this way they may have proper forum for redress of their judicial problems. In Pakistan there are different types of educational institutions for different social class and creating divide in the society therefore they are of the view that there should be the same focused system of education, regardless of class or creed for harmony and unity.

Public sector secondary school teachers' attitudes toward democracy are negative. This is true for all three subcategories: 1. acceptance of democracy, 2. attitude toward government, and 3. attitude toward government institutions. The people of Pakistan generally and teachers especially are not happy with the uncertainty, economic recession, power breakdown, poor law and order, terrorism in the country. The lack of good governance has lead people to develop negative attitudes toward government and institutions. Moreover, the elected representatives try to do everything right or wrong to grab money for themselves and to please their voters to remain in the power so they interfere in the smooth functioning of the institutions. Whenever there is democracy in the country there is less academic work and more transfers and postings. The fruit of democracy for the majority of teachers is bitter. In true sense the democracy in Pakistan is not to serve the nation but to get the personal benefits. The teachers as members of the society have never experienced true benefits of democracy rather they face miseries of so called and distorted democracy how they can accept the democracy when the power groups are also continuously playing their role. As the study was delimited to public school teachers, future researchers are recommended to include the private sector school teachers and consider the effect of education, age, ethnicity, media consumption, social integration, religious beliefs, urban-rural environments, happiness, and life satisfaction on attitude toward democracy.

\section{AUTHORS INFORMATION}

Dr. Muhammad Sarwar is presently working as post-doctoral fellow in the Institute of Education, University of Worcester, UK whereas he is Assistant Professor in Department of Education, University of Sargodha, Pakistan. He did his M.Phil. in Education from Allama Iqbal Open University, Pakistan and Ph.D. in Education from University Institute of Education and Research, UAAR, Pakistan. E-mail: m.sarwar@worc.ac.uk 
Dr. Muhammad Imran Yousuf is working as Assistant Professor in Division of Continuing Education, Pir Mehr Ali Shah Arid Agriculture University, Rawalpindi, Pakistan. He did his M.Phil. in Teacher Education from Allama Iqbal Open University, Pakistan and Ph.D. in Education from University Institute of Education and Research, UAAR, Pakistan. E-mail: dr.imran@uaar.edu.pk

Dr. Shafqat Hussain is presently working as post-doctoral fellow at UK whereas he is Assistant Professor in Department of Education, GC University, Faisalabad, Pakistan. He did his M.Phil. in Education from Allama Iqbal Open University, Pakistan and Ph.D. in Education from University Institute of Education and Research, UAAR, Pakistan. Email: drhssn@yahoo.com

\section{REFERENCES}

1. Acemoglu, D and Robinson. J. A. (2006). Economic Origins of Dictatorship and Democracy. Cambridge,: Cambridge University Press.

2. Akbari, H.(2008). Educating Business Professionals For Year 2010 And Beyond: Six Critical Management Themes And Skills To Emphasize. International Business \& Economics Research Journal, 7(7), 59-60.

3. Braithwaite, V. \& Levi, M. (1998). Trust and Governance. New York: Russell Sage Foundation.

4. Christensentom, L. P. (2003). Trust in Government - the Significance of Attitudes Toward Democracy, the Public Sector and Public Sector Reforms. Washington D.C: Stein Rokkan Centre For Social Studies, Be R G E N University Research Foundation.

5. Daniel, S., Benjamin G. B., Robert R. B. (2006). Authoritarian Attitudes, Democracy, and Policy Preferences among Latin American Elites. American Journal of Political Science, Vol. 50, No. 3, July 2006, , 50 (3), 606-620.

6. Hodgson, N. (2008). Citizenship Education, Policy, And The Educationalization Of Educational Research. Educational Theory, 58 (4).

7. Hu, A. K.. (2003). Attitudes toward Democracy Between Mass Publics and Elites in Taiwan and Hong Kong. Taipei: Asian Barometer Project Office.

8. Nathan, A. (2004). Traditional Social Values, Democratic Values, and Political Participation. Taipei: National Taiwan University and Academia Sinica.

9. Osler, Audrey \& Starkey, Hugh (2005). Changing citizenship: Democracy and inclusion in education. New York: Open University Press.

10. Pajares, F. (1992). Teachers' beliefs and educational research: Cleaning up a messy construct. Review of Educational Research, 62, 307-332.

11. Pike, M. A. (2008). Faith in citizenship? On teaching children to believe in liberal democracy. British Journal of Religious Education, 30 (2), 113-122.

12. Rothstein, B., Stolle, D., 2002. How political institutions create and destroy social capital: an institutional theory of generalized trust, Presented at the 98th meeting of the American Political Science Association, Boston, August 2002.

13. Shechtman, Z. (2002). Validation of the Democratic Teacher Belief Scale (DTBS). Assessment in Education, 9, 363-377.

14. Tessler Mark, Altinoglo Ebru. (2004). Political Culture in Turkey: connections among attitudes toward democracy, the military and Islam. Democratization, 11 (1), 22-51

15. WEBB, P. (2005). Political Parties and Democracy: The Ambiguous Crisis. Democratization , 12 (5), 633 650 . 
NOTES 